\title{
PENGARUH MODEL PROBLEM BASED LEARNING TERHADAP KETERAMPILAN BERPIKIR KRITIS SISWA SMP
}

\author{
Y. Auliana, N. M. Pujani, P. Prima Juniartina \\ Program Studi S1 Pendidikan IPA \\ Universitas Pendidikan Ganesha \\ Singaraja, Indonesia
}

e-mail: \{yunda.auliana,made.pujani,prima.juniartina\}@undiksha.ac.id

\begin{abstract}
Abstrak
Penelitian ini bertujuan menganalisis perbedaan keterampilan berpikir kritis antara siswa yang dibelajarkan dengan model problem based learning (PBL) dan siswa yang dibelajarkan dengan model kooperatif tipe student team achievement division (STAD). Penelitian ini termasuk penelitian eksperimen semu (quasi experiment) dengan rancangan non-equivalent pretest-posttest control group design. Populasi dalam penelitian ini adalah seluruh siswa kelas VII SMP Negeri 3 Singaraja semester genap tahun pelajaran 2018/2019 yang berjumlah 367 siswa. Sampel penelitian dipilih dengan teknik cluster random sampling. Sampel yang digunakan dalam penelitian ini tersebar dalam 2 kelas dengan berjumlah 64 siswa, yaitu kelas eksperimen yang dibelajarkan dengan model PBL dan kelas kontrol yang dibelajarkan dengan model kooperatif tipe STAD. Instrumen yang digunakan dalam penelitian ini adalah tes uraian keterampilan berpikir kritis. Data dianalisis menggunakan statistik deskriptif dan anakova satu jalur dengan taraf signifikansi $5 \%$. Hasil penelitian menunjukkan bahwa 1) terdapat perbedaan keterampilan berpikir kritis antara siswa yang dibelajarkan dengan model PBL dan siswa yang dibelajarkan dengan model kooperatif tipe STAD dengan angka taraf signifikan diperoleh lebih kecil dari 0,05 (sig. $<0,05$ ). Siswa yang belajar dengan model PBL secara signifikan memiliki keterampilan berpiki kritis yang lebih tinggi dibandingkan dengan model kooperatif tipe STAD $\left.\left(\left|\mu_{1}-\mu_{2}\right|=16,000>L S D=1,9994\right), 2\right)$ gain score ternormalisasi keterampilan berpikir kritis siswa yang belajar dengan model PBL berkualifikasi sedang $(<\mathrm{g}\rangle=0,41)$, sedangkan gain score ternormalisasi keterampilan berpikir kritis siswa yang belajar dengan model kooperatif tipe STAD berkualifikasi rendah $(<\mathrm{g}>=0,08)$.
\end{abstract}

Kata Kunci: problem based learning, student team achievement division,keterampilan berpikir kritis.

\footnotetext{
Abstract

This research purposes analyze the critical thinking skills of students with problem based learning model (PBL) and students by cooperative models of division type student team achievement division (STAD). This research includes quasi-experimental research with non-equivalent pretest-posttest control group design. The population in this research were all seventh grade students of class VII SMPN 3 Singaraja semester 2018/2019 academic year totaling 367 students. The research sample was chosen by cluster random sampling technique. The sample used in this study was spread in 2 classes with a total of 64 students, namely the experimental class which was taught by PBL model and control class which was taught by the cooperative type STAD model. The instrument used in this study was a description of critical thinking skills. Data were analyzed using descriptive statistics and anakova one way with a significance level of $5 \%$. The results showed that 1) there were differences in critical thinking skills between students who were taught with the PBL model and students who were taught by the cooperative type STAD model with a significant level of numbers obtained less than 0.05 (sig. <0.05). Students who learn with the PBL model significantly have higher critical thinking skills than the cooperative type STAD model $(|\mu 1-\mu 2|=16,000>\operatorname{LSD}=1,9994)$, 2) gain score normalized critical thinking skills students who learn with the model PBL is moderately qualified $(<\mathrm{g}\rangle=0.41)$, while the gain score normalizes critical thinking skills of students who study with cooperative type STAD model with low qualifications $(<\mathrm{g}>=0.08)$.
} 
Keywords: problem based learning, student team achievement division, critical thinking skills.

\section{PENDAHULUAN}

Pendidikan memiliki peranan yang penting dalam kehidupan berbangsa dan bernegara, yaitu untuk menjamin kelangsungan kehidupan dan perkembangan bangsa. Pendidikan tertuang dalam UU No. 20 Tahun 2003 tentang Sistem Pendidikan Nasional. Pendidikan adalah usaha sadar dan terencana untuk mewujudkan suasana belajar dan proses pembelajaran agar siswa secara aktif mengembangkan potensi dirinya untuk memiliki kekuatan spiritual keagamaan, pengendalian diri, kepribadian, kecerdasan, akhlak mulia, serta keterampilan yang diperlukan dirinya, masyarakat, bangsa, dan Negara (Depdiknas, 2003).

Pemerintah Indonesia telah melakukan berbagai upaya untuk meningkatkan mutu pendidikan, mulai dari kurikulum Rencana Pembelajaran tahun 1947 disempurnakan menjadi kurikulum Rencana Pelajaran Terurai tahun 1952, disempurnakan lagi menjadi kurikulum Rencana Pendidikan tahun 1964, kemudian disempurnakan kembali menjadi Kurikulum Berbasis Kompetensi (KBK) tahun 2004, kemudian disempurnakan menjadi Kurikulum Tingkat Satuan Pendidikan (KTSP) hingga disempurnakan lagi menjadi Kurikulum 2013. Proses pembelajaran dalam Kurikulum 2013, peran siswa lebih dominan dibandingkan dengan guru, sehingga Kurikulum 2013 bersifat student center. Kurikulum 2013 menuntut mengembangkan keterampilan berpikir tingkat tinggi atau biasa disebut dengan HOTS (higher order thinking skills). Salah satu keterampilan berpikir tingkat tinggi adalah keterampilan berpikir kritis (critical thinking). Redhana (2010) menyatakan keterampilan berpikir kritis merupakan kemampuan berpikir bagi seseorang dalam membuat keputusan yang dapat dipercaya dan bertanggung jawab yang mempengaruhi hidup seseorang.

Nugraha, Suyitno \& Susilaningsih (2017) menyatakan bahwa siswa dengan keterampilan berpikir kritis tinggi cenderung mampu mengkaji ulang pendapat yang diberikan berdasarkan pengetahuan yang sudah ia miliki, siswa juga cenderung dapat menunjukkan solusi pemecahan masalah yang paling efektif menurutnya di antara solusi-solusi yang diberikan.

Pembelajaran IPA melatih siswa menggunakan dan mengembangkan kemampuan berpikirnya. Sebagai salah satu mata pelajaran pokok yang diajarkan di sekolah, IPA seharusnya mampu mengembangkan segala potensi yang ada pada siswa, salah satunya adalah kemampuan berpikir kritis (Redhana, 2012). Kenyataannya, keterampilan berpikir kritis siswa di kategorikan masih rendah. Hal ini dapat ditinjau dari laporan Data Trends In Mathematics and Science Study (TIMSS) pada tahun 2015 mengungkapkan bahwa skor sains di Indonesia berada pada urut ke 45 dari 48 negara dengan skor 397. Rata-rata kemampuan sains siswa Indonesia pada tiap domain kognitif (knowing, applying, dan reasoning) masih rendah. Bidang sains persentasi pencapaian domain kognitif siswa pada aspek knowing hanya 37 jawaban benar, aspek applying 29 jawaban benar, dan aspek reasoning) 26 jawaban benar dari 171 butir soal IPA. Kemampuan sains peserta didik Indonesia di bawah nilai rata-rata (500) dan secara umum berada pada tahapan terendah atau yang dikenal low international benchmark. Berdasarkan data yang dipaparkan, hal ini membuktikan bahwa kualitias kemampuan sains di Indonesia masih rendah (Balitbang, 2015).

Rendahnya tingkat keterampilan berpikir kritis siswa di tunjukan juga dari temuan di lapangan. Suardana \& Selamet (2017) menyatakan rendahnya keterampilan berpikir kritis ditemukan pula pada siswa SMA di Kabupaten Buleleng, Provinsi Bali. Hasil menunjukkan bahwa skor rata-rata keterampilan berpikir kritis siswa SMA pada tingkat tinggi, menengah, dan tingkat rendah adalah 59,0 (kategori cukup), 43,1 (kategori rendah), dan 34,7 (kategori sangat rendah). Hal ini menunjukkan bahwa kualitias sumber daya manusia masih rendah. Hal ini juga penelitian yang dilakukan oleh Sujamen, et al. (2018) bahwa kualitas pendidikan sains di Indonesia, termasuk Bali cenderung 
rendah. Beberapa kabupaten di Bali menunjukkan bahwa siswa-siswa sekolah menengah atas (SMA) jatuh ke dalam kualifikasi kelas rendah dengan skor rata-rata 49, 38 dalam skala 0-100.

$$
\text { Sanjaya (2006) mengemukakan }
$$

bahwa salah satu kelemahan proses pembelajaran yang dilaksanakan para guru adalah kurang adanya usaha pengembangan kemampuan berpikir siswa. Berdasarkan observasi di sekolah Faktor yang menyebabkan dikarenakan siswa kurang terlatih mengembangkan keterampilan berpikir dalam memecahkan masalah dan menerapkan konsep-konsep yang dipelajari di sekolah ke dalam dunia nyata. Guru menggunakan model pembelajaran kooperatif tipe student team achievement division (STAD). Model pembelajaran kooperatif tipe STAD adalah salah satu model dari banyak model pembelajaran kooperatif dengan menggunakan kelompok-kelompok kecil beranggotakan empat sampai lima siswa secara heterogen dengan diawali penyampaian tujuan pembelajaran, penyampaian materi pelajaran, kegiatan kelompok, kuis serta penghargaan kelompok (Slavin dalam Abdullah, 2013). Secara umum kegiatan dalam model pembelajaran kooperatif tipe STAD terdiri dari tujuh tahapan pembelajaran, yaitu: 1) penyampaian tujuan pembelajaran dan motivasi siswa, 2) penyampaian materi pelajaran, 3) pembentukan kelompok belajar, 3) belajar dalam kelompok dan bimbingan kelompok belajar, 4) kuis, 5) evaluasi, dan 6) enghargaan kelompok. Proses pembelajaran dengan model pembelajaran kooperatif tipe STAD, guru mengalami kesulitan dalam menciptakan situasi belajar yang kondusif dan kurang dapat bekerjasama dengan teman yang kurang akrab dan adanya dominasi dari siswa yang pandai (Trianto, 2013). Kondisi ini berimplikasi pada kebiasaan siswa untuk menghafal setiap materi pelajaran yang berpengaruh pada rendahnya keterampilan berpikir kritis siswa.

Berdasarkan permasalahan yang telah dipaparkan perlu adanya perbaikan kualitas dan inovasi pembelajaran terutama model pembelajaran yang dapat mengarahkan siswa memecahkan masalah dan memfasilitasi kegiatan dalam upaya meningkatkan keterampilan berpikir kritis siswa. Salah satu model pembelajaran yang dapat membantu meningkatkan keterampilan kritis siswa adalah model problem based learning (PBL). Santyasa (2011) menyatakan, model pembelajaran problem based learning adalah suatu model pembelajaran yang menggunakan masalah dunia nyata sebagai suatu konteks bagi pelajar untuk mengajar tentang keterampilan berpikir kritis dan keterampilan pemecahan masalah, serta untuk memperoleh pengetahuan serta konsep yang essensial dari materi pembelajaran. Arends (2007) menyatakan problem based learning (PBL) akan dapat membantu peserta didik untuk mengembangkan keterampilan berpikir dan mengatasi masalah, mempelajari peran-peran orang dewasa, dan menjadi pembelajaran mandiri. Abddullah (2013) menyatakan bahwa model problem based learning (PBL) merupakan pembelajaran yang penyampaiannya dilakukan dengan cara menyajikan suatu permasalahan, mengajukan pertanyaan-pertanyaan, memfasilitasi penyelidikan dan membuka dialog. Secara umum kegiatan dalam model problem based learning terdiri dari 5 langkah pembelajaran, yaitu: 1) orientasi siswa pada masalah, 2) mengorganisasi siswa untuk belajar, 3) membimbing pengalaman individu/kelompok, 4) mengembangkan dan menyajikan hasil karya, 5) menganalisis dan mengevaluasi proses pemecahan masalah.

Beberapa penelitian mengemukakan bahwa model problem based learning dapat meningkatkan keterampilan berpikir kritis siswa. Penelitian yang dilakukan oleh Ejin (2016) bahwa pembelajaran IPA berdasarkan model problem based learning untuk melatihkan penguasaan konsep dan keterampilan berpikir kritis siswa SD, telah valid, praktis dan efektif sehingga layak digunakan dalam kegiatan pembelajaran dengan hasil analisis Independent Sample T-test. Hasil penelitian Sujamen et.al (2018) hasilnya menunjukkan bahwa pembelajaran dengan model PBL dapat meningkatkan keterampilan berpikir kritis siswa dalam pembelajaran fisika ( $\alpha=5 \%$ ) rata-rata untuk tiga kelompok jatuh ke dalam kategori tinggi. Hasil penelitian yang dilakukan oleh 
Irwandi et. al dan Saparudin Saroni (2018) bahwa hasil penelitian menunjukkan bahwa PBL adalah strategi pembelajaran yang baik untuk mengembangkan kemampuan berpikir kritis dan kognitif siswa.

Berdasarkan latar belakang yang telah dikemukakan, maka dapat dirumuskan permasalahan yaitu apakah terdapat perbedaan keterampilan berpikir kritis antara siswa yang dibelajarkan model problem based learning dengan siswa yang dibelajarkan model kooperatif tipe student team achievement division?. Tujuan yang ingin dicapai dalam penelitian ini adalah untuk menganalisis perbedaan keterampilan berpikir kritis antara siswa yang dibelajarkan model problem based learning dengan siswa yang dibelajarkan model kooperatif tipe student team achievement division.

\section{METODE}

Penelitian ini termasuk penelitian eksperimen semu dengan rancangan nonequivalent pretest-posttest control group design. Populasi dalam penilitian ini adalah siswa-siswi kelas VII di SMP Negeri 3 Singaraja tahun pelajaran 2018/2019 berjumlah 367 siswa. Proses randomisasi yang dilakukan untuk mendapatkan sampel penelitian yaitu dengan menggunakan teknik cluster random sampling. Sampel yang digunakan dalam penelitian tersebar dalam 2 kelas dengan jumlah 64 siswa yang yaitu kelas eksperimen dan kelas kontrol.

Data dalam penelitian ini adalah keterampilan berpikir kritis siswa yang diperoleh dengan tes keterampilan berpikir kritis siswa. Tes keterampilan berpikir kritis siswa yang digunakan berupa soal uraian. Pada penelitian ini terdapat tiga variabel, yaitu variabel bebas, variabel terikat, dan variabel kovariat. Variabel bebas pada penelitian ini adalah model pembelajaran. Model pembelajaran yang digunakan dalam penelitian ini yaitu model problem based learning pada kelompok eksperimen dan model pembelajaran kooperatif tipe student team achievement division pada kelompok kontrol. Variabel terikat pada penelitian ini adalah keterampilan berpikir kritis siswa. Variabel kovariat pada penelitian ini adalah keterampilan berpikir kritis awal siswa yang berfungsi sebagai kontrol statistik karena selain variabel bebas terdapat variabel lain yang dapat mempengaruhi variabel terikat.

Sebelum digunakan dalam penelitian, instrumen harus diujicobakan. Pengujian instrumen meliputi: 1) uji validitas, 2) uji indeks daya butir, 3) uji indeks kesukaran butir, dan 5) uji reliabilitas. Tes keterampilan berpikir kritis siswa tersebut berjumlah 10 butir soal yang mewakili semua indikator dalam pembelajaran. Tes yang digunakan pada saat pretest dan posttest adalah tes yang sama.

Data yang diperoleh dianalisis secara deskriptif dan anakova satu jalur. Metode analisis deskriptif digunakan untuk mengetahui tinggi rendahnya keterampilan berpikir kritis siswa dalam pembelajaran IPA. Data yang diperoleh dari hasil tes kemampuan awal dan akhir dianalisis untuk mendapatkan skor peningkatan gain score ternormalisasi $(<\mathrm{g}>)$. Metode anakova satu jalur digunakan untuk mengetahui hubungan antara kovariat, yaitu keterampilan berpikir kritis awal siswa dengan keterampilan berpikir kritis siswa. Sebelum dilakukan pengujian hipotesis dengan anakova satu jalur terlebih dahulu data harus memenuhi beberapa asumsi yang meliputi: 1) Uji Normalitas sebaran data menggunakan Kolmogorov-Smirnov dengan bantuan SPSS 16.0 for windows. Kriteria pengujian yang digunakan adalah data berdistribusi normal apabila angka signifikansi yang dihasilkan lebih besar dari 0,05. 2) Uji Homogenitas mengguanakan Levene's Test of Wquality of Error Variance dengan bantuan SPSS 16.0 for windows. Kriteria pengujian yang digunakan adalah data memiliki varain yang sama, apabila angka signifikansi yang dihasilkan lebih besar dari 0,05. 3) Uji linieritas dengan melihat angka signifikansi pada deviation from linearity berbantuan SPSS 16.0 for windows. Kriteria pengujian yang digunakan adalah angka signifikansi pada deviation from linearity lebih besar dari 0,05. Jika data hasil penelitian telah memenuhi persyaratan normalitas, homogenitas varian, dan linieritas maka anakova satu jalur dapat dilanjutkan.

Pengujian hipotesis melalui anakova satu jalur bantuan SPSS 16.0 for windows. Kriteria pengujiannya adalah $\mathrm{HO}$ ditolak jika nilai signifikansi lebih kecil dari 0,05. Hal 
tersebut mengisyaratkan terdapat perbedaan keterampilan berpikir kritis antara siswa yang belajar dengan menggunakan model pembelajaran problem based learning dan kooperatif tipe student teams achievement division. Apabila hasil uji $F$ melalui anakova satu jalur menunjukkan terdapat perbedaan antara rata-rata kelompok, maka diperlukan uji lanjut untuk menentukan seberapa besar derajat perbedaannya.

Uji lanjut dalam penelitian ini menggunakan Least Significant Diference (LSD). Formula yang digunakan untuk menghitung Least Significant Difference (LSD) adalah formula Montgomery. Namun sebelum uji tersebut dilakukan, yang terlebih dahulu harus diketahui yaitu besarnya nilai Mean Difference (I-J) dan $M S_{E}$ (Mean
Square Error). Kriteria yang digunakan adalah $\mathrm{H}_{0}$ ditolak harga mutlak $\left|\mu_{\mathrm{m} 1}-\mu_{\mathrm{m} 2}\right|>\mathrm{LSD}$ yang artinya terdapat perbedaan nilai rata-rata variabel dependent pada masing-masing kelompok sampel. Taraf signifikansi yang digunakan dalam uji ini sebesar 0,05. Uji ini memanfaatkan bantuan SPSS 16.0 for Windows.

\section{HASIL DAN PEMBAHASAN}

Deskripsi data hasil penelitian membahas tentang profil pretest, posttest, gain score ternormalisasi keterampilan berpikir kritis.Nilai rata-rata (M) keterampilan berpikir kritis siswa pada kelompok eksperimen dan kontrol sebelum pembelajaran (pretest) dan sesudah pembelajaran (posttest) disajikan pada Tabel 1.

Tabel 1. Profil Pretest dan Posttest Keterampilan Berpikir Kritis

\begin{tabular}{lccccc}
\hline \multicolumn{1}{c}{ Kelas } & $\begin{array}{c}\text { Model } \\
\text { Pembelajaran }\end{array}$ & Pretest & Postest & $<\mathbf{g}>$ & Kualifikasi \\
\hline Kelas & PBL & 28,6 & 37,3 & 0,41 & Sedang \\
Eksperimen & STAD & 27,5 & 29,3 & 0,08 & Rendah \\
Kelas Kontrol & & & & &
\end{tabular}

Nilai rata-rata keterampilan berpikir kritis siswa disetiap indikator pada kelompok eksperimen dan kontrol sebelum pembelajaran (pretest) dan setelah pembelajaran (posttets) menunjukkan bahwa siswa yang belajar dengan model problem based learning dilihat dari hasil pretest dan posttest mengalami peningkatan. Berdasarkan Tabel 1 skor rata-rata pretest untuk kelompok eksperimen sebesar 28,6, sedangkan untuk kelas kontrol sebesar 27,5. Skor posttest yang dicapai pada kelompok eksperimen sebesar 37,3, sedangkan skor posttest untuk kelas kontrol sebesar 29,3. Nilai gain score ternormalisasi yang dicapai kelas eksperimen sebesar 0,41 memiliki kualifikasi sedang, sedangkan gain score ternormalisasi yang dicapai kelas kontrol sebesar 0,08 memiliki kualifikasi rendah. $\mathrm{Hal}$ ini menunjukkan bahwa hasil gain score ternormalisasi pada kelas eksperimen lebih tinggi daripada hasil gain score ternormalisasi pada kelas kontrol. Berikut ini grafik profil gain score ternormalisasi keterampilan berpikir kritis disajikan pada Gambar 1

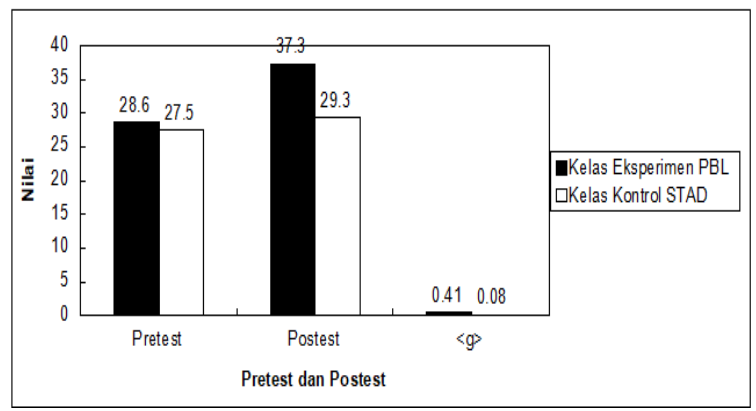

Gambar 1

Nilai Gain Score Ternormalisasi Pretest dan Posttes

Santyasa (2011) menyatakan, model pembelajaran problem based learning adalah suatu model pembelajaran yang menggunakan masalah dunia nyata sebagai suatu konteks bagi pelajar untuk mengajar tentang keterampilan berpikir kritis dan keterampilan pemecahan masalah, serta untuk memperoleh pengetahuan serta konsep yang essensial dari materi pembelajaran. Ibrahim \& Nur (dalam 
Rusman, 2011) mengemukakan bahwa pembelajaran berbasiss masalah merupakan salah satu pendekatan pembelajaran yang digunakan untuk merangsang berpikir kritis tingkat tinggi siswa dalam situasi yang berorientasi pada masalah dunia nyata, termasuk didalamnya belajar bagaimana belajar. Model problem based learning merupakan pembelajaran yang menggunakan masalah nyata (autentik) yang tidak terstruktur (iil-structured) dan bersifat terbuka sebagai komteks bagi peserta didik untuk mengembangkan keterampilan menyelesaikan masalah dan berpikir kritis serta sekaligus membangun pengetahuan baru (Fathurrohman, 2015).

Temuan dalam penelitian ini sejalan dengan hasil penelitian yang telah dilakukan oleh Handayani, Kurniati dan Agustina (2015), dalam penelitiannya yang berjudul pengaruh model problem based learning terhadap keterampilan berpikir kritis siswa pada sub materi pokok alat indra. Hasil tes $N$-gain score keterampilan berpikir kritis pada kelas eksperimen lebih tinggi dari pada kelas kontrol. $\mathrm{N}$-gain score kelas eksperimen yang menggunakan model problem based learning sebesar 0,45 kriteria sedang, sedangkan $\mathrm{N}$-gain score kelas kontrol tanpa menggunakan model problem based learning sebesar 0,27 kriteria rendah.

Adapun beberapa alasan yang menjadi dasar mengapa model problem based learning dalam pencapaian keterampilan berpikir kritis lebih tinggi dibandingkan dengan model pembelajaran kooperatif tipe student teams achievement division, adalah sebagai berikut. Menurut Suci (dalam Bungel, 2014) secara teoritik model pembelajaran problem based learning memiliki karakteristik yang membedakannya dengan model pembelajaran yang lainnya yaitu pembelajaran yang bersifat student centered atau berpusat pada siswa. Arends (2007) menyatakan problem based learning akan dapat membantu peserta didik untuk mengembangkan keterampilan berpikir dan mengatasi masalah, mempelajari peran-peran orang dewasa, dan menjadi pembelajaran mandiri. Savery (2006) menyatakan problem based learning adalah sebuah model pembelajaran yang berpusat pada siswa, siswa didorong melakukan penelitian, mengintegrasikan teori dengan praktik dan dunia nyata, serta mengaplikasikan pengetahuan dan keterampilan untuk menghasilkan solusi yang tepat terhadap sebuah masalah.

$$
\text { Konteks belajar dalam model }
$$

problem based learning dapat dideskripsikan sebagai proses belajar melalui pengalaman belajar yang direfleksikan dalam memecahkan suatu permasalahan-permasalahan tidak terstruktur secara mendalam sehingga muncul suatu pemahaman baru dari proses belajar tersebut. Terdapat lima tahap langkah-langkah model problem based learning, yaitu: 1) orientasi siswa pada masalah, 2) mengorganisasi siswa untuk belajar, 3) membimbing pengalaman individu/kelompok, 4) mengembangkan dan menyajikan hasil karya, dan 5) menganalisis dan mengevaluasi proses pemecahan masalah.

Secara operasional empiris penerapan model problem based learning di kelas menggunakan Lembar Kerja Siswa (LKS) problem based learning yang sifatnya tidak terstruktur, sedangkan model pembelajaran kooperatif tipe student teams achievement division menggunakan LKS yang sifatnya lebih terstruktur. LKS PBL dalam penyajiannya dimulai dengan penyajian masalah/pertanyaan yang kontekstual. Tujuannya adalah untuk menggali pengetahuan awal yang dimiliki siswa. Permasalahan kontekstual tersebut, siswa kemudian mengajukan jawaban sementara (hipotesis) sesuai dengan pengetahuan awal mereka. Membuktikan kebenaran dari hipotesis yang diajukan, siswa kemudian melakukan observasi melalui kegiatan eksperimen atau melalui telaah pustaka dari beberapa sumber-sumber referensi relevan. Hal ini tentunya dapat memberikan peluang bagi siswa untuk mengembangkan kemampuan berpikir siswa secara optimal dalam kegiatan pembelajaran.

Siswa diberikan kesempatan untuk menerapkan konsep yang diperoleh pada permasalahan baru yang sifatnya realistik sesuai dengan keseharian pebelajar. Dengan demikian dapat diyakini bahwa problem based learning dapat 
mengembangkan keterampilan berpikir kritis menjadi lebih baik.

Menurut Oktavia, Usmeldi \& Yohandri (2018) kegiatan yang dilakukan dalam pembelajaran mendorong siswa untuk dapat terapkan dalam hidup. Ini berarti proses penyelesaian masalahnya bukan hanya berharap siswa untuk memahami materi yang dipelajari, tetapi bagaimana penerapannya bisa diaplikasikan dalam kehidupan sehari-hari. Melalui aplikasi pembelajaran, peserta didik akan merasakan pentingnya belajar sehingga mereka memperoleh makna yang mendalam tentang apa yang dia terpelajar.

Sebagai tindak lanjut dari hasil gain score ternormalisasi pretest dan posttest yang diperoleh pada kelas eksperimen dan kontrol, maka dilakukan analisis deskripsi terhadap jawaban siswa pada setiap indikator keterampilan berpikir kritis siswa yang belajar dengan model problem based learning dan siswa yang belajar dengan model pembelajaran kooperatif tipe student teams achievement division. Tujuannya untuk mengetahui ketercapaain indikator keterampilan berpikir kritis pada Indikator keterampilan berpikir kritis yang digunakan ada lima yaitu interpretasi, analisis, evaluasi, inferensi dan eksplanasi. Skor maksimal setiap buit soal per-indikator adalah 5 dan minimal adalah 0 . Skor yang diperoleh pada setiap indikator keterampilan berpikir kritis siswa kemudian dianalisis menggunakan gain score ternormalisasi yang disajikan pada Tabel 2.

Tabel 2. Profil Ketercapaian Indikator Keterampilan Berpikir Kritis Siswa

\begin{tabular}{|c|c|c|c|c|c|c|c|c|}
\hline \multirow{2}{*}{$\begin{array}{c}\text { Indikator } \\
\text { Keterampilan Berpikir } \\
\text { Kritis }\end{array}$} & \multicolumn{8}{|c|}{ Model Pembelajaran } \\
\hline & Pretest & $\begin{array}{c}\text { PBL } \\
\text { t Posttest }\end{array}$ & $<g>$ & Kualifikasi & Pretest & $\begin{array}{l}\text { STAD } \\
\text { t Posttest }\end{array}$ & $t<\mathrm{g}>$ & Kualifikasi \\
\hline Interpretasi & 3,00 & 3,55 & 0,28 & Rendah & 2,81 & 2,77 & $-0,02$ & Rendah \\
\hline Analisis & 3,13 & 3,89 & 0,41 & Sedang & 3,09 & 2,78 & $-0,16$ & Rendah \\
\hline Evaluasi & 2,44 & 3,73 & 0,50 & Sedang & 2,42 & 3,16 & 0,29 & Rendah \\
\hline Infrensi & 2,98 & 3,66 & 0,34 & Sedang & 2,84 & 3,03 & 0,09 & Rendah \\
\hline Eksplanasi & 2,77 & 3,84 & 0,48 & Sedang & 2,58 & 2,94 & 0,15 & Rendah \\
\hline
\end{tabular}

Berdasarkan Tabel 3 bahwa secara keseluruhan indikator ketercapain gain score ternormalisasi pada siswa yang belajar dengan model problem based learning lebih besar dibandingkan siswa yang belajar dengan model pembelajaran kooperatif tipe student teams achievement division. Nilai gain score ternormalisasi terhadap ketercapaian indikator keterampilan berpikir kritis siswa untuk kelompok PBL dan STAD disajikan pada grafik histogram Gambar 2.

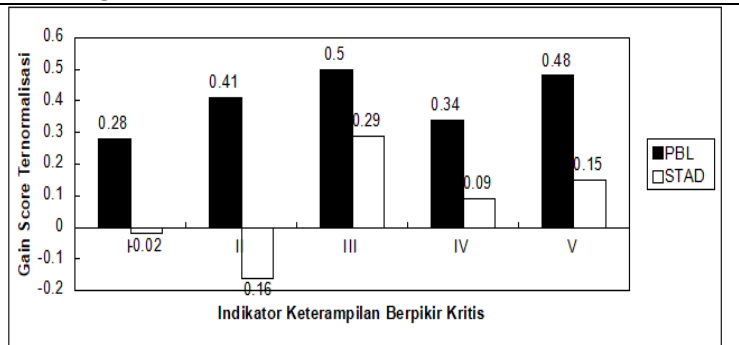

Gambar 2

Grafik Ketercapaian Indikator Keterampilan Berpikir Kritis Siswa

Keterangan Indikator:

I = Indikator Interpretasi

II = Indikator Analisis

III = Indikator Evaluasi

IV = Indikator Infrensi

$\mathrm{V}=$ Indikator Eksplanasi 
Nilai gain score ternormalisasi pada indikator interpretasi, siswa yang belajar dengan model problem based learning menunjukkan ketercapaian sebesar 0,28 (kualifikasi rendah) lebih tinggi dari pada siswa yang belajar dengan model pembelajaran kooperatif tipe student teams achievement division sebesar $-0,02$ (kualifikasi rendah). Hal ini dikarenakan pada sintak orientasi pada masalah, siswa terbiasa diberikan masalah terlebih dahulu sebagai interpretasi untuk dapat berpikir kritis. Indikator selanjutnya yaitu pada indikator analisis. Model problem based learning memberikan masalah yang relevan diperkenalkan pada awal siklus instruksi dan digunakan untuk memberikan konteks dan motivasi untuk pembelajaran yang mengikuti (Michael dalam Argaw et al, 2017).

Gain score ternormalisasi pada indikator analisis siswa yang belajar dengan model problem based learning menunjukkan ketercapaian sebesar 0,41 (kualifikasi sedang) lebih tinggi dari pada siswa yang belajar dengan model pembelajaran kooperatif tipe student teams achievement division sebesar $-0,16$. Hal ini dikarenakan, siswa mengorganisasi untuk belajar. siswa belajar untuk menganalisis suatu masalah atau situasi dengan mengidentifikasi masalah dalam bentuk representasi yang dimaksudkan untuk mengekspresikan keyakinan, penilaian, pengalaman, alasan, informasi, atau pendapat. Setelah siswa memahami konteks masalahnya, siswa diminta untuk mengidentifikasi dan menganalisis pernyataan masalah seperti, informasi apa yang diberikan, dan apa informasi diperlukan (Ahamad et.al, 2017).

Analisis suatu masalah atau situasi yang dilakukan akan membawa siswa untuk mengatur strategi dan teknik serta menjalankannya dengan benar melalui pemikirannya. Selain itu, guru membantu siswa untuk melakukan refleksi atau evaluasi terhadap penyelidikan mereka dan proses yang mereka gunakan sehingga sekaligus dapat melatih kemampuan analisis siswa seperti sintak menganalisis dan mengevaluasi proses pemecahan masalah.

Nilai gain score ternormalisasi pada indikator evaluasi, siswa yang belajar dengan model problem based learning menunjukkan ketercapaian 0,50 (kualifikasi sedang) lebih tinggi dari pada siswa yang belajar dengan model pembelajaran kooperatif tipe student teams achievement division sebesar 0,17 (kualifikasi rendah). Hal ini dikarenakan siswa terlatih untuk menganalisis suatu permasalahan sehingga pada saat evaluasi siswa lebih mudah untuk menjawab pertanyaan.

Nilai gain score ternormalisasi pada indikator infrensi siswa yang belajar dengan model problem based learning menunjukkan ketercapaian 0,34 (kualifikasi sedang) lebih tinggi dari pada siswa yang belajar dengan model pembelajaran kooperatif tipe student teams achievement division sebesar 0,09 (kualifikasi rendah). Hal ini dikarenakan siswa mengumpulkan informasi yang sesuai, melaksanakan eksperimen untuk mendapatkan penjelasan dan melakukan pemecahan masalah. Guru membimbing siswa untuk mengidentifikasi dan memilih sumber yang dibutuhkan untuk menyusun suatu kesimpulan, sesuai dengan tahap ketiga yaitu membimbing pengalaman individual/kelompok. Guru juga membantu siswa dalam merancang dan menyiapkan karya yang sesuai seperti laporan, dan membantu untuk menyampaikan kepada orang lain seperti tahap keempat mengembangkan dan menyajikan hasil karya.

Nilai gain score ternormalisasi pada indikator eksplanasi siswa yang belajar dengan model problem based learning menunjukkan ketercapaian 0,48 (kualifikasi sedang) lebih tinggi dari pada siswa yang belajar dengan model pembelajaran kooperatif tipe student teams achievement division sebesar 0,15 (kualifikasi rendah). Hal ini dikarenakan, siswa diarahkan untuk menyatakan hasil pemikiran, menjelaskan alasan berdasarkan pertimbangan bukti-bukti yang sudah diperoleh dari pengamatan ataupun sumber-sumber buku yang relevan. Jadi, secara keseluruhan dapat disumpukan bahwa pembelajaran dengan model problem based learning lebih baik dalam meningkatkan keterampilan berpikir kritis siswa dibandingkan dengan model pembelajaran kooperatif tipe student 
teams achievement division. Model problem based learning dibiasakan untuk menganalisis sebuah permasalahan dengan memberdayakan kemampuan keterampilan berpikirnya. Hal ini yang menyebabkan rata-rata keterampilan berpikir kritis siswa yang belajar dengan model problem based learning lebih baik dibandingkan dengan model pembelajaran kooperatif tipe student teams achievement division.

Temuan ini didukung oleh peneliti Ulfah et al (2018) menyatakan bahwa model pembelajaran problem based learning lebih baik daripada model pembelajaran penemuan untuk menumbuhkan kemampuan berpikir kritis peserta didik dalam pembelajaran PPKn di Sekolah Menengah Kejuruan Negeri 1 Magelang. Hal ini juga sejalan dengan penelitian Amanda et al (2018) bahwa ketuntasan indikator berpikir kritis sebesar 57,3\% dan didukung dengan skor peningkatan yang tinggi terhadap kemampuan berpikir kritis siswa. Berdasarkan analisis data, dapat diperoleh kesimpulan bahwa implementasi model problem based learning efektif dalam meningkatkan keterampilan berpikir kritis siswa. Berdasarkan kajian tersebut bahwa hasil penelitian ini konsisten dengan gasil penelitian sebelumnya.

Uji statistik sebagai uji prasyarat dilakukan dengan menggunakan uji normalitas, homogenitas dan uji linearitas. Hasil uji normalitas menunjukkan bahwa sebaran keterampilan berpikir kritis siswa baik dari kelompok eksperimen maupun dari kelompok kontrol berdistribusi normal karena nilai signifikansi yang diperoleh lebih besar dari 0,05. Pada uji homogenitas menunjukkan bahwa data keterampilan berpikir kritis siswa antara kelompok eksperimen dan kontrol mempunyai varian yang sama yaitu tidak ada perbedaan keterampilan berpikir kritis siswa yang dimiliki tiap kelompok karena nilai signifikansi yang diperoleh lebih besar daripada 0,05. Pada uji linearitas menunjukkan bahwa data yang dimiliki bersifat linier karena nilai signifikansi kurang dari 0,05 .

Hasil analisis kovariat pada penelitian ini menunjukkan bahwa antara model problem based learning (PBL) dan model pembelajaran kooperatif tipe student teams achievement division terdapat perbedaan yang signifikan pada keterampilan berpikir kritis siswa. Hal ini dapat ditunjukkan dengan skor statistik $\mathrm{F}=$ 229,899 dengan angka signifikansi 0,000. Angka signifikansi ini lebih kecil dari 0,05. Jadi, hasil belajar siswa secara signifikan $(\mathrm{sig}<0,05)$ dipengaruhi oleh model pembelajaran yang digunakan dalam pembelajaran. Berdasarkan hasil analisis yang diperoleh menunjukkan bahwa model problem based learning (PBL) lebih baik diterapkan dibandingkan dengan model pembelajaran kooperatif tipe student teams achievement division dalam upaya meningkatkan keterampilan berpikir kritis siswa.

Pengujian hipotesis dilakukan dengan uji Anakova satu jalur. Adapun hipotesis yang diajukan dan akan diuji dalam penelitian ini adalah sebagai berikut.

1. $H_{0}: \mu_{1}=\mu_{2}$ yaitu tidak terdapat perbedaan keterampilan berpikir kritis antara siswa yang dibelajarkan dengan model problem based learning dan siswa yang dibelajarkan model pembelajaran kooperatif tipe student teams achievement division.

2. $H_{1}: \mu_{1} \neq \mu_{2}$ yaitu terdapat perbedaan keterampilan berpikir kritis antara siswa yang dibelajarkan dengan model problem based learning dan siswa yang dibelajarkan dengan model pembelajaran kooperatif tipe student teams achievement division. Ketentuannya jika angka signifikansi lebih kecil dari 0,05 berarti $\mathrm{H}_{0}$ ditolak, sedangkan jika angka signifikansi lebih besar dari 0,05 (sig.>0,05) berarti $\mathrm{H}_{0}$ diterima. Secara ringkas hasil uji Anakova satu jalur disajikan pada Tabel 3

Tabel 3

Ringkasan Hasil UjiAnakova Satu Jalur

Tests of Between-Subjects Effects 


\begin{tabular}{lccccc}
\hline \multicolumn{7}{c}{ Dependent Variable:Keterampilan Berpikir Kritis } \\
\hline \multicolumn{1}{c}{ Source } & $\begin{array}{c}\text { Type III Sun of } \\
\text { Squares }\end{array}$ & $\boldsymbol{d f}$ & Mean Square & $\boldsymbol{F}$ & Sig. \\
Corrected Model & 4185,309 & 2 & 2092,654 & 130,732 &, 000 \\
Intercept & 1678,729 & 1 & 1678,729 & 104,873 &, 000 \\
Pretest & 89,309 & 1 & 89,3093 & 5,579 &, 021 \\
ModelPembelajaran & 3680,052 & 1 & 3680,052 & 229,899 &, 000 \\
Eror & 976,441 & 61 & 16,007 & & \\
Total & 289784,000 & 64 & & & \\
Corrected Total & 5161,750 & 63 & & & \\
\hline
\end{tabular}

Hasil analisis menunjukkan bahwa $F$ untuk model pembelajaran besarnya 229,899 dengan angka signifikansi yang diperoleh lebih kecil dari 0,05 (sig.<0.05). Dengan demikian $\mathrm{H}_{0}$ ditolak dan $\mathrm{H}_{1}$ diterima. Hal tersebut berarti terdapat perbedaan keterampilan berpikir kritis antara siswa yang dibelajarkan dengan model problem based learning dan siswa yang dibelajarkan model pembelajaran kooperatif tipe student teams achievement division.

Hasil tindak lanjut LSD menunjukkan bahwa signifikansi skor rata-rata keterampilan berpikir kritis antara siswa yang belajar dengan model problem based learning lebih tinggi dibandingkan dengan skor rata-rata keterampilan berpiki kritis siswa yang belajar dengan model pembelajaran kooperatif tipe student teams achievement division $(\Delta \mu=16,000>$ LSD $=$ 1,9994). Hal tersebut berarti pengaruh model problem based learning terhadap keterampilan berpikir kritis siswa secara statistik lebih baik dibandingkan dengan pengaruh model pembelajaran kooperatif tipe student teams achievement division.

Hasil penelitian ini sejalan dengan hasil penelitian yang dilakukan oleh Aryasta, Subrata \& Pujani (2014), dalam penelitian tentang pengaruh model problem based learning terhadap keterampilan berpikir kritis siswa kelas X IPA SMA Negeri 1 Singaraja. Hasil uji lanjut LSD menunjukkan bahwa keterampilan berpikir kritis siswa yang belajar dengan model PBL lebih tinggi dibandingkan model DI. Dengan demikian, keterampilan berpikir kritis siswa yang belajar dengan model PBL lebih baik dibandingkan keterampilan berpikir kritis siswa yang belajar dengan model DI.

\section{SIMPULAN DAN SARAN}

Berdasarkan hasil dan pembahasan dalam penelitian ini, dapat disimpulkan bahwa terdapat perbedaan keterampilan berpikir kritis antara siswa yang dibelajarkan dengan model problem based learning dan siswa yang dibelajarkan dengan model pembelajaran kooperatif tipe student teams achievement division. Model problem based learning dapat mengembangkan keterampilan berpikir kritis lebih baik dibandingkan dengan model pembelajaran kooperatif tipe student teams achievement division $\left(\left|\mu_{\mathrm{m} 1}-\mu_{\mathrm{m} 2}\right|>\mathrm{LSD}\right)$.

Berdasarkan hasil penelitian yang telah dilakukan, peneliti melalui tulisan ini menyampaikan beberapa saran sebagai berikut.

1. Hasil penelitian menunjukkan bahwa siswa yang belajar dengan model problem based learning secara signifikan memperoleh keterampilan keterampilan berpikir kritis yang lebih baik daripada siswa yang belajar dengan model pembelajaran kooperatif tipe student teams achievement division. Oleh karena itu, model problem based learning dapat digunakan sebagai salah satu alternatif strategi pembelajaran yang dapat digunakan di sekolah karena sesuai dengan paradigma konstruktivisme.

2. Penelitian ini hanya bertujuan untuk mengetahui adanya pengaruh model problem based learning terhadap keterampilan berpikir kritis siswa. Kepada peneliti lain yang tertarik untuk melakukan penelitian dengan model problem based learning disarankan melakukan penelitian pada aspek pembelajaran yang berbeda, misalnya hasil belajar, prestasi belajar, motivasi belajar, dan lain sebagainya. 
3. Penelitian kedepannya disarankan agar lebih memperlihatkan dan mengendalikan faktor-faktor lain yang dapat mempengaruhi keterampilan berpikir kritis, seperti motivasi, IQ, kemampuan berpikir formal, dan sebagainya.

\section{DAFTAR PUSTAKA}

Abdullah, S. R. 2013. Inovasi Pembelajaran, Jakarta: PT. Rineka Cipta.

Ahamad, H., et.al. 2017. Implementation of problem-based learning in geometry lessons. Journal of Physics: Conference Series. Volume 1(10). Hal 1-14.

Amanda, S., Muharrami, L, K \& Rosidi, I. 2018. Peningkatan Kemampuan Berpikir Kritis Siswa pada Pembelajaran IPA Menggunakan Model Pembelajaran Berbasis Masalah yang Berbasis SETS. Journal of Natural Science Education Reseach. Volume 1(1). Hal 57-64.

Argaw, A.S et.al. 2017. "The Effect of Problem Based Learning (PBL) Instruction on Students' Motivation and Problem Solving Skills of Physics". Journal of Mathematics Science and Technology Education. Volume 13(3). Hal 857-871.

Bungel, M. F. 2014. Penerapan model pembelajaran problem based learning untuk meningkatkan hasil belajar siswa kelas VIII SMP Negeri 4 Palu pada materi prisma. Jurnal Elektronik Pendidikan Matematika Tadulako. Volume 2(1). Hal 46-54.

Arends, R. I. 2007. Learning to teach (seventh edition). New York: McGrawhill Company.

Aryasta, I. N., Subratha, I, N., \& Pujani, N, M. 2014. Pengaruh Model Problem Bsed Learning Terhadap Berpikir Kritis Siswa Kelas X IPA SMA Negeri 1 Singaraja Tahun Ajaran 2013/2014. E-journal Undiksha. Volume 1(1). Hal 56-64.

Balitbang. 2015. Laporan Hasil TIMSS 2015. Jakarta: Kemendikbud.

Depdiknas. 2003. Undang-Undang Republik Indonesia Nomor 20 Tahun 2003 Tentang Sistem Pendidikan Nasional. Jakarta: Depdiknas.
Ejin, S. 2016. Pengaruh Model Problem Based Learning Terhadap Pemahaman Konsep dan Keterampilan Berpikir Kritis Siswa Kelas IV SD Jambu Hilir Baluti 2 pada Mata Pelajaran IImu Pengetahuan Alam. Jurnal Pendidikan. Volume1(1). Hal 65-71.

Fathurrohman, M. 2015. Paradigma Pembelajaran Kurikulum 2013 Strategi Alternatif Pembelajaran di Era Global. Yogyakarta: KALIMEDIA.

Handayani, D, E., Kurniati, T \& Agustina, T, W. 2015, Pengaruh Model Problem Based Learning Terhadap Keterampilan Berpikir Kritis Siswa pada Materi Pokok Alat Indra. Jurnal Program Studi Pendidikan Biologi. Volume 5(1). Hal 59-66.

Irwandi., W. N \& Topano, A. 2018. Pengaruh Problem Based Learning Terhadap Kemampuan Berpikir Kritis dan Kognitif Siswa SMA. Prosiding Seminar Nasional Pendidikan Biologi Volume 1(1). Hal 191-196.

Nugraha, A.J., Suyitno, $H$ \& Susilaningsih, E. 2017. Analisis Kemampuan Berpikir Kritis Ditinjau dari Keterampilan Proses Sains dan Motivasi Belajar melalui Model PBL. Journal Primary of Education. Volume 6(1). Hal 35-43.

Oktavia, R.A., Usmeldi \& Yohandri. 2018. Development of Physics Learning Material Based on Problem Based Learning by Integrating Local Wisdom West Sumatra to Improve Critical Thinking Ability of Students. International Journals of Sciences and High Technologies. Volume 6(2). Hal 544-553.

Redhana, I. W. 2012. Model Pembelajaran Berbasis Masalah dan Pertanyaan Socratik Untuk Meningkatkan Keterampilan Berpikir Kritis Siswa. FMIPA.Universitas Pendidikan Ganesha. Jurnal Cakrawala Pendidikan. Volume 1(3). Hal 351-365.

Redhana, I. W. 2010. Pengaruh Model Pembelajaran Berbasis Peta Argumen terhadap Keterampilan Berpikir Kritis Siswa pada Topik laju Reaksi. Jurnal 
Pendidikan dan Pengajaran, Volume 43(2). Hal 141-148.

Rusman, $2011 . \quad$ Model-Model Pembelajaran. Jakarta: PT. Raja Grafindo Persada.

Sanjaya, W. 2006. Strategi pembelajaran berorientasi standar proses pendidikan. Jakarta: Kencana Predana Media Group.

Santyasa, I W. 2011. Pembelajaran Inovatif. Universitas Pendidikan Ganesha. Diktat Perkuliahan (tidak diterbitkan).

Suardana, I. N \& Selamet, I. N. K. 2012. Analisis Keterampilan Berpikir Kritis Siswa SMA di Kabupaten Buleleng. Prosiding Seminar Nasional MIPA.

Saroni, S., Hasan., Nasran \& Simbuldin. 2018. Kemampuan Berpikir Kritis dan Minat Belajar Mahasiswa pada Mata Kuliah Fisiologi Tumbuhan Melalui Model Pembelajaran PBL dan Inkuiri dengan Menggunakan Media Mind Mapping d Program Studi Pendidikan Biologi Universitas Muhammadiyah Bengkulu. Prosiding Seminar Nasional Pendidikan Biologi. Volume 1(12). Hal 474-481.

Savery, J. R. 2006. Overview of problem-based learning: Definitions and distinctions. Interdisciplinary Journal of Problem-based Learning Volume1(1). Hal 9-20.

Sujamen, R., Poedjiastuti, S \& Poedjiastuti, B. 2018. The Effectiveness of problem-based hybrid learning model in physics teaching to enhance critical thinking of the students of SMAN. Journal of Physics: Conference Series. Volume 1(11). Hal 1-7.

Trianto. 2013. Mendesain Model Pembelajaran Inovatif-Progresif. Surabaya: Kencana.

Ulfah, R, A., Prasetyo, D \& Marzuki. 2018. Pengaruh Model Pembelajaran PPKn Terhadap Kemampuan Berpikir Kritis dan Sika Demokratis. Citizenship Jurnal Pancasila dan Kewarganegaraan. Volume 6(2). Hal 126-139. 